\title{
Latvian Peat Industry - to Be or Not to Be?
}

\author{
Jelena Lukjanova ${ }^{1}$, Tatyana Odinokova ${ }^{1}$, and Vitolds Zahars ${ }^{2}$ \\ ${ }^{1}$ ISMA University, 1 Lomonosova Str., Bld.6, LV-1019, Riga, Latvia \\ ${ }^{2}$ Daugavpils University, Parades st. 1, Daugavpils, LV-5401, Latvia
}

\begin{abstract}
This article is devoted problems sector which traditional Latvia face - peat extraction and processing industry. Potential industry, dynamic of development, and contribution to country's economy has been provided as well. Specifics use of peat extracted in Latvia, namely, use in horticulture, is determined. Unresolved industry problems were identified, threat to industry related to implementation of European Green Investment Plan was also indicated.
\end{abstract}

\section{Introduction}

Latvia is not rich in mineral or fuel resources and depends of imports from other countries, in particular oil, natural gas, coal, metals and minerals. Main resources include dolomite, quartz sand, clay, sand and gravel, sapropel, peat. Extraction and processing of peat is a traditional branch of Latvia. First publication on the extraction and use of peat in Latvia appeared in 1797. Nowadays, peat extraction makes significant contribution to country's economy, however, it is necessary to note the presence of a number of unresolved problems. According to experts [1-5], undoubtedly, industry has enormous potential for further development. The task is to ensure effective management of the peat extraction industry, while taking into account both interests of European Community and the national interests of Latvia.[6-8]

\section{Materials and methods}

In this research authors made: Central Statistical Office of Latvia development dynamics of peat extraction industry in Latvia, on its contribution to country's economy; Documents of Latvian Ministry of Environmental Protection and Regional Development regarding sustainable development planning of peat extraction industry; Documents of the Ministry of Economy of Latvia regarding long-term energy strategy of the state; Data from Latvian Peat Association; European Commission (2020) Country Report Latvia 2020.[9]

\section{Results and discussion}

Peat is one of the most significant natural resources of Latvia. Latvia takes the seventh place in the share of peat bogs in country, in turn, Latvia takes the 14th place in world peat bogs. Total area of swamps is $6401 \mathrm{~km} 2$, or $9.9 \%$ of country's territory. Peat fund includes 
5799 deposits. Of these, 7 have an area of more than 5000 ha, 87 - an area of 1001 to 5000 ha, 109 - an area of 501 to 1000 ha. $69.7 \%$ of wetlands are in an untouched state, $23.4 \%$ are drained, $3.9 \%$ are used for peat extraction, $1.8 \%$ of peat reserves have already been used and $1.2 \%$ are equipped for reservoirs.

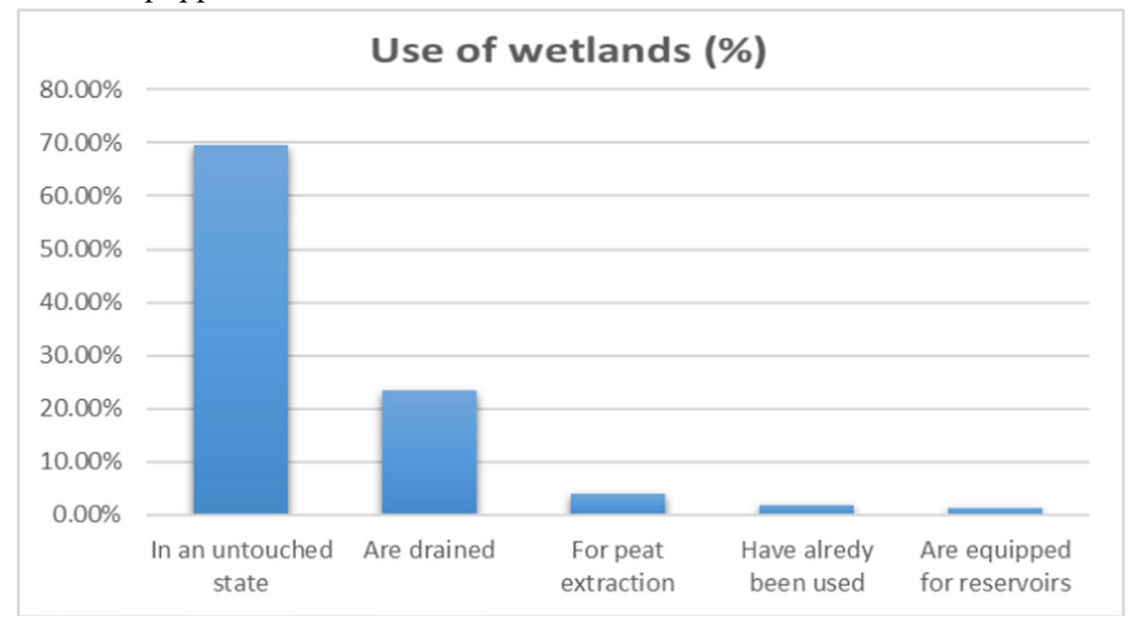

Fig. 1. Use of wetlands [10].

Peat resources are not precisely defined and may amount to 11.3 billion $\mathrm{m} 3$ or 1.7 billion tons. Of total resources, 1.1 billion tons are fuel peat with an average calorific value of $5.2-5.3 \mathrm{kcal} / \mathrm{kg}$.

\section{Peat resources distribution by regions of Latvia,\%}

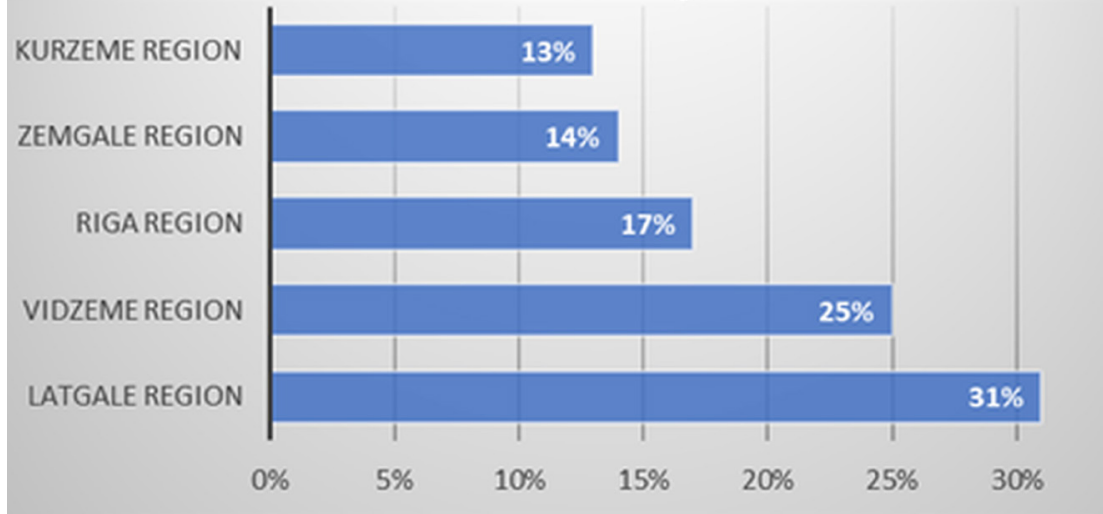

Fig. 2. Peat resources distribution by regions of Latvia, \% [11]

Due to various circumstances, significant part of resources is not suitable for use. Peat fund includes 5799 deposits. Largest share of peat deposits is in Latgale region - $31 \%$ of total resources. $25 \%$ is located in Vidzeme region, $17 \%$ belongs to Riga region, and $13 \%$ and $14 \%$ of peat deposits are concentrated in Kurzeme and Zemgale regions, respectively.

Peat extraction is not only one of traditional industries, it makes a significant contribution to Latvian economy. Until the end of the 20th century, about $70 \%$ of peat extracted in Latvia was used as raw material for production of thermal energy. Currently, 
situation has changed. Only $2 \%$ of obtained peat is used for energy production, and $95 \%$ for the cultivation of food and ornamental plants. Peat, according to experts, is the most costeffective substrate with the smallest "ecological footprint" and it plays an important role in the production of healthy food all over the world. This is fundamental difference from other EU countries, where it is extracted mainly for energy production. Process of reducing share of peat for energy production began in Latvia since 1990. During this period, use of peat for energy production decreased by $98.8 \%$, and share of peat in total energy consumption in 2017 reached $0.01 \%$.

In 1992, peat extraction in Latvia was maximum. However, already in next 1993, decline in total production begins, then slight recovery and sharp drop in 1998. In general, over the past years, industry has developed rather unevenly. It should be noted that this fact already in 1990, most of the peat extracted was used in agriculture, and not in the energy sector. In 2019 , only $2 \%$ of extracted peat was used in energy sector of Latvia. Table 1 presents volumes of peat extraction and its use in EU countries in 2017.

Table 1. Peat extraction volumes in EU countries (2017) and its use (thousand $\mathrm{m}^{3}$ ) [12].

\begin{tabular}{|l|c|c|c|}
\hline Country & Peat extraction & Peat use in horticulture & Energy consumption \\
\hline Ireland & 17100 & 4100 & 13000 \\
\hline Sweden & 3100 & 1700 & 1400 \\
\hline Finland & 11097 & 1000 & 9500 \\
\hline Estonia & 3784 & 2648 & 1135 \\
\hline Latvia & 4988 & 4900 & 88 \\
\hline Lithuania & 2500 & 1788 & 712 \\
\hline Germany & 4400 & 4400 & 0 \\
\hline
\end{tabular}

Fact that peat extraction plays significant role in Latvian economy is evidenced by fact that for each ton of peat there are between 106 and 108 euros of added value. Total contribution of peat production to Latvian economy is 14,566 euros per hectare. If we compare this indicator with another traditional industry - dairy farming, then here figure is 400 euros per hectare.

Given that licensed peat extraction is carried out on an area of 25 thousand hectares, this ensures the production of 1 to 1.5 million tons of peat per year.

Peat extraction has a positive effect on employment, especially in regions such as Latgale, with traditionally high unemployment rates. Total number of employees is from 1800 to 3000 people in various regions of Latvia. Such dynamics is associated with seasonal fluctuations in peat extraction. Moreover, wages of people working in peat mining and processing enterprises are usually higher than not only average in region, but also average in country.

The fact that in 2018 Latvian peat extraction companies paid 12 million taxes, and these are only taxes administered by the State Revenue Service (SRS), also testify to great contribution to Latvian economy. This amount did not include the tax on natural resources, as well as taxes that are paid for services related to peat extraction. On average, peat extraction industry pays from 18 to 18.5 million euros per year to the state budget. Taking into account taxes paid by related companies, total amount of taxes is on average 50 million euros per year. Peat production in Latvia has undergone significant changes over the past 10 years. In 2009, peat extraction in Baltic countries amounted to about 850 tons in Latvia and Estonia, and about 700 tons in Lithuania. In 2018, Latvia turned out to be leader in this field among the Baltic countries, producing about 1,400 tons, while Estonia produces 800 tons, and Lithuania just over $700.58 \%$ of available area of peat in Latvia belongs to state, which it leases and, accordingly, country receives more than $60 \%$ of extracted peat from these facilities. 


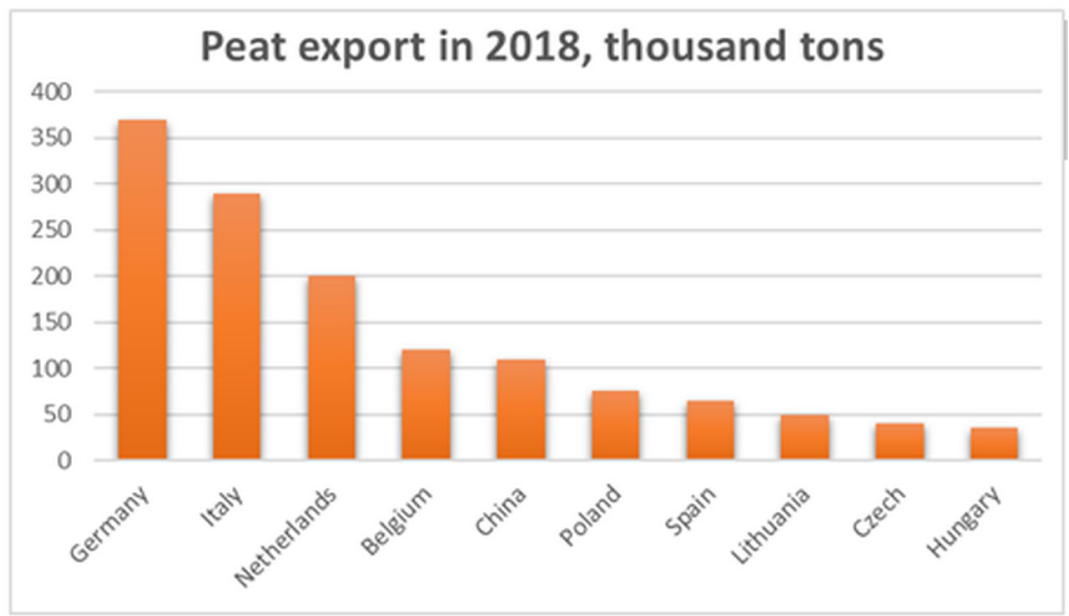

Fig. 3. Peat extraction in the Baltic States 2009-2018, tons [13].

According to information provided by State Environmental Service, in 201866 companies were engaged in peat extraction, and 15 plants were engaged in its processing and packing of peat. An important factor affecting activities of enterprises in the industry are weather conditions. It should be noted that enterprises compete in the foreign market, as More than $95 \%$ of peat is exported. Negative factor for them is rent for land, which in Latvia averages 178 euros / hectare, while in Estonia 10 euros / hectare, and in Lithuania - 8 euros / hectare.

According to Ingrida Krihere (member of the board of Latvian Association of Peat Producers), industry is negatively affected by fact that "enterprises must pay rent regardless of possibility of peat extraction and if the extraction is not carried out for three years, then the license is canceled."[14]

Peat extraction also plays an important role in Latvian exports. So, in 2018, total export of peat reached more than 1800 thousand tons or 180 million euros. In 2009, Latvia exported peat to 87 countries, and in 2018 already to 112 countries. Latvian peat is mainly exported to Europe, partly to Asia and America. In Europe, main buyers are Germany, Italy and the Netherlands. In Asia, largest buyers are China (more than 100 million tons), South Korea and Japan (30 thousand tons each). On American continent, main buyers are USA (a little more than 30 thousand tons) and Brazil (22 thousand tons) [15]. The top 10 main buyers of Latvian peat are shown in Figure 4.

Dynamics of development of peat extraction in Latvia allows us to talk about the prospects of this industry for the national economy. Peat is not an inexhaustible resource, but slowly renewable resource. Given the favorable climatic conditions, annual increase in peat significantly exceeds its production. About 1.6 million tons of peat is accumulated per year, average rate of its accumulation is approximately $2 \mathrm{~mm}$ per year. However, over tenyear period, an average of 0.95 million tons were mined annually. This means that Latvia does not currently extract and use all the peat growth. Currently $32 \%$ of peat used in professional gardening in Europe is peat produced in Latvia.

It should be noted that $70 \%$ of substrates that are used in professional gardening all over the world are peat substrates. Peat is actively used in food production. According to experts, by 2050 the world's population can reach 10 billion, which means that demand for substrates will increase. 


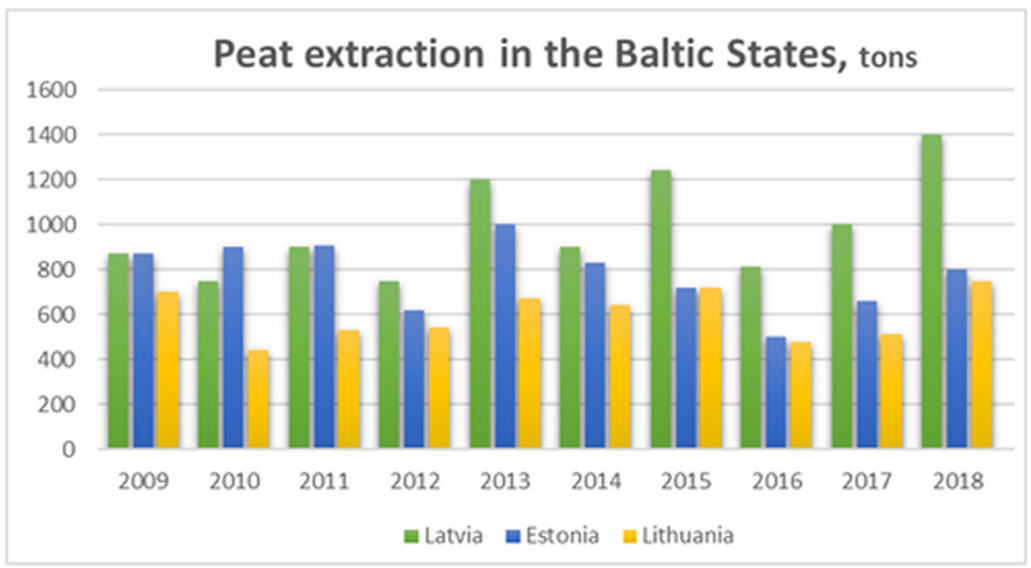

Fig. 4. Peat exports in 2018, top 10 countries thousand tons / million euros [15].

It is estimated that the demand for substrates for food products, ornamental plants and tree seedlings will increase by $415 \%$ [16]. It should be noted and problems faced by industry. One of them is problem of rent, as already mentioned. Latvian companies pay rents that are not only higher than in the Baltic countries, but higher than in Canada or Russia. This indicates inefficiency of peat resources management, as discourages the studied industry. Second problem is lack of unified methodology for determining market value of rent of peat deposits using underground resources. Each certified appraiser uses its own methodology, which inhibits the development of the industry. Since 2015, there has been a discussion of this issue, which has not yet been resolved.

As already mentioned above, two main areas in which peat is used are energy and agriculture. In Latvia, peat is mainly extracted for horticultural purposes, small part - for production of activated carbon and for other purposes. Peat is mainly used as substrate. It should be noted that use of peat in Latvia for energy production is the lowest among European countries producing peat. Peat is mainly used by individual households. Nevertheless, use of peat in energy sector until recently was considered as promising direction. Thus, one of the goals outlined in the Energy Strategy of Latvia until 2030, is stated as "promoting the use of the potential of local energy resources, including peat extraction [17]. Latvian Energy Development Guidelines for 2014-2020 also indicate a certain potential for producing energy peat from peatlands with total area of about 4,000 ha to ensure energy independence of country. Production volume may reach at least 700 thousand tons of energy peat per year [18].

Now imports account for $70 \%$ of Latvia's energy consumption. Latvia is highly dependent on natural gas and lacks energy. At the same time, energy value of Latvian peat reserves suitable for production is estimated at 663 terawatt hours (TWh). An increase in production of energy peat to 700,000 tons will make it possible to produce up to 2.1 million MWh of energy, and, accordingly, replace the equivalent amount of natural gas in the amount of 99855000 euros. Thus, use of energy peat for heating can reduce Latvia's dependence on imports of fossil energy, reduce gas monopoly, reduce energy costs, increase the possibility of exporting wood, and create the basis for new jobs. Therefore, as stated in the project of the main installations for the sustainable use of peat for 2018-2050, from the point of view of sustainable use of peat resources, the extraction and use of fuel peat is desirable and should be supported [11].

Project of main installations for the sustainable use of peat for 2018-2050 provides, in particular, number of economic activities aimed at ensuring the sustainable development of this sector of the economy. 
Table 2. Economic activity to implement a sustainable strategy the use of peat [11].

\begin{tabular}{|l|l|}
\hline \multicolumn{1}{|c|}{ Activities } & \multicolumn{1}{|c|}{ Results } \\
\hline Extraction, use of peat & $\begin{array}{l}\text { Extraction and use of peat with low added value; } \\
\text { high value added mining and processing }\end{array}$ \\
\hline $\begin{array}{l}\text { Peat extraction and preparation for } \\
\text { energy sector }\end{array}$ & $\begin{array}{l}\text { Production of peat briquettes and combined } \\
\text { briquettes }\end{array}$ \\
\hline $\begin{array}{l}\text { Peat extraction and preparation for } \\
\text { chemical industry }\end{array}$ & Value Added Products \\
\hline $\begin{array}{l}\text { Use of swamps in forestry and } \\
\text { agriculture }\end{array}$ & $\begin{array}{l}\text { Berry plantations; nurseries; plantations of energy } \\
\text { willow (other trees) }\end{array}$ \\
\hline
\end{tabular}

Thus, draft long-term strategy for use of peat provides for diverse use of this natural resource of Latvia.

But it is important to note fact that this document is still under development, although it was supposed to complete this work in 2017. At this moment, it is necessary to make significant changes in connection with the European Commission's European Green Rate Investment Plan, which provides for financing for transition to more environmentally friendly energy resources for those regions that are more dependent on the extraction and use of fossil fuels in the energy sector. So, Latvia is supposed to allocate funding in amount of 68 millions euros for measures to switch to "climate neutrality" for the period up to 2050. In addition, European Commission undertakes to compensate for the loss of jobs by creating new and reprofiling the workforce.

Shortly before the announcement of plan, peat used in energy sector was also included in list of fossil fuel resources, that is, burned and contributing to the strengthening of the greenhouse effect. In January 2020, Ministry of Environmental Protection and Regional Development (VARAM) [11] opened a discussion with responsible sectors on the proposals prepared by the European Commission as part of the new European Green Growth Strategy for a fair transformation mechanism in the EU to finance measures to reduce emissions and develop a competitive economy based on climate neutrality. On February 25, 2020, European Commission published guidelines on the use of financing for transition to more environmentally friendly energy resources, which identifies priority investment areas in Latvia [8].

Formulation of guidelines for peat sector in Latvia is ambiguous, although European Commission has publicly confirmed that this sector will not be closed. Representatives of Latvian Peat Association express concern - will the industry be able to produce peat in the future or will it have to be imported?[13]. According to representatives of association, in documents of European Commission it is necessary to distinguish between energy peat and peat for gardening. As mentioned above, 95\% of peat extracted in Latvia is used in horticulture and this is significantly different from other EU countries, where peat is extracted mainly for energy. In Latvia, only $2 \%$ of extracted peat is used for energy purposes. According to representatives of the association, Latvia has not been extracting peat for energy needs since 2002 and has achieved the goals of the European Green Deal initiative, at least in the field of energy peat extraction, almost 20 years ago. Therefore, logical question arises: is the allocation of financing in the amount of 68 million euros aimed at solving the problems of extracting $2 \%$ of energy peat? And will the implementation of another European initiative lead to the destruction of the Latvian peat mining industry, especially since the country already has the sad experience of destroying sugar factories and fishing vessels to please the European Union Directives.

It should be noted that Latvian Peat Association supports the European Ecological Course and is ready to seek solutions to reduce greenhouse gas emissions in this sector and 
is convinced that the extraction and processing of peat for horticulture and forestry is already oriented towards sustainability, modernization and development [12].

\section{Conclusion}

In this situation, Latvian authorities have a difficult task - to receive European financing in the amount of about 68 million euros over the next seven years and prevent the loss of the peat extraction and processing industry. In general, number of tasks have been accumulated in the industry today that need to be addressed. It is necessary:

- Assess use of swamps, determine which part of swamps is protected, which can be used for peat extraction;

- Determine required or permissible production areas and volumes of peat extraction during the year;

- To determine such a methodology for calculating the cost of land rental that will provide an understandable auction price, including both peat extraction of all types and reclamation. - Improve regulatory framework for the regulation of peat sector of the economy. In particular, to develop and adopt a long-term strategy for managing the peat industry of Latvia, in line with the realities of today, taking into account the green course of the EU and the preservation and further development of this industry;

- Provide participants in peat industry with accurate information on availability of resources;

- Develop and verify national methods for calculating greenhouse gas emissions (emissions);

- In the long run, find solutions to reduce emissions or prevent their increase;

- Unify the terminology used in the industry;

- Solve the problem of training specialists for the industry, as well as related industries land reclamation and hydrology of swamps

- Strengthen work on the creation and implementation of new innovative products.

In the context of European Green Deal investment plan, Latvia, which claims to finance activities to switch to "climate neutrality" for the period up to 2050, may lose its peat extraction and processing industry. In short term, there is a desire to get money by solving a non-existent problem, but this will destroy the industry, which is of great importance in the food production chain and huge export potential.

\section{References}

1. I. Kolechkina, I. Verchagina, E. Eltsova, M. Petrova, E3S Web Conf., 134, 02004 (2019)

2. M. Petrova, M. Tepavicharova, L. Dikova, E3S Web Conf., 41, 04017 (2018)

3. N. Kurmanov, M. Petrova, S. Suleimenova, E3S Web Conf., 105, 04045 (2019)

4. R. Pukala, M. Petrova, E3S Web Conf., 105, 04034 (2019)

5. V. Koval, G. Duginets, O. Plekhanova, A. Antonov, M. Petrova, Entrepreneurship and Sustainability Issues, 6:4, 1922-1937 (2019)

6. M. Petrova, V. Koval, M. Tepavicharova, A. Zerkal, A. Radchenko, N. Bondarchuk, Journal of Security and Sustainability Issues, 9:3, 897-907 (2020)

7. I. Gryshova, M. Petrova, M. Tepavicharova, A. Diachenko, T. Gutsul, Entrepreneurship and Sustainability Issues, 7:1, 690-703 (2019)

8. K. Mussapirov, J. Djalkibaev, G. Kurenkeyeva, A. Kadirbergenova, M. Petrova, L. Zhakypbek, Entrepreneurship and Sustainability Issues, 7:2, 1480-1495 (2019) 
9. Country Report Latvia 2020, Assessment of progress on structural reforms, prevention and correction of macroeconomic imbalances, and results of in-depth reviews under (Regulation European Comission, Brussels, 2020)

10. Latvian Center for Environment, Geology and Meteorology. URL: https://www.meteo.lv/lapas/geologija/zemes-dzilu-resursi/derigie-izraktenibuvmaterialu-izejvielas-kudra-un-sapropelis-/kudra/kudra?id=1242\&nid=594

11. Ministry of Environmental Protection and Regional Development, Guidelines for the sustainable use peat 2018-2050. URL: http://www.varam.gov.lv/lat/likumdosana/normativo_aktu_projekti/normativo_aktu_pr ojekti_vides_aizsardzibas_joma/?doc $=252$

12. Latvian Peat Association, Küdras ieguves nozare Latvijā. URL: http://www.latvijaskudra.lv/upload/nozare_vai_parkartoties.2020.pdf

13. Latvian Peat Association, Guidelines for the use of the Fair Restructuring Fund. URL: http://www.latvijaskudra.lv/

14. Latvian peat extraction strategy - 2016. URL: https://www.lsm.lv/raksts /dzive-stils/vide-un-dzivnieki/izstradas-latvijas-kudras-ieguves-strategiju.a166344/

15. Central Statistical Bureau. URL: http://www.csb.gov.lv/statistikas

16. Latvian Public Media, Izstrādās Latvijas kūdras ieguves stratēóiju. URL: https://www.lsm.lv/raksts/dzive--stils/vide-un-dzivnieki/izstradas-latvijas-kudrasieguves-strategiju.a166344/

17. Ministry of Economics, Latvijas Energétikas ilgtermina stratēgija 2030 - konk urētspējīga enerğētika sabiedrībai. URL: https://www.em.gov.lv/

18. Ministry of Economics, Energétikas attīstības pamatnostādnes 2016-2020. URL: https://www.em.gov.lv/lv/nozares_politika/atjaunojama_energija_un_kogeneracija/nor mativie_akti_un_politikas_planosanas_dokumenti_/

19. M. Tepavicharova, L. Dikova, V. Zahars, E3S Web Conf., 105, 04029 (2019) 